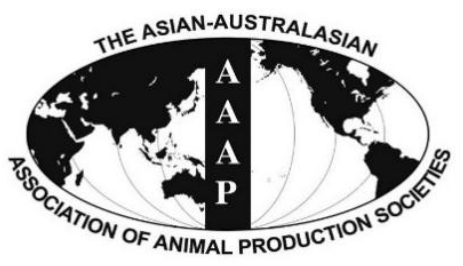

Open Access

Asian Australas. J. Anim. Sci.

Vol. 28, No. 9 : 1362-1370 September 2015

http://dx.doi.org/10.5713/ajas.15.0078

www.ajas.info

pISSN 1011-2367 elSSN 1976-5517

\title{
Effect of Dietary Protein Levels on Composition of Odorous Compounds and Bacterial Ecology in Pig Manure
}

\author{
Sungback Cho, Okhwa Hwang, and Sungkwon Park ${ }^{1, *}$ \\ National Institute of Animal Science, Rural Development Administration, Wanju 565-851, Korea
}

\begin{abstract}
This study was performed to investigate the effect of different levels of dietary crude protein (CP) on composition of odorous compounds and bacterial communities in pig manure. A total of 48 male pigs (average initial body weight $45 \mathrm{~kg}$ ) fed diets containing three levels of dietary $\mathrm{CP}(20 \%, 17.5 \%$, and $15 \%)$ and their slurry samples were collected from the pits under the floor every week for one month. Changes in composition of odorous compounds and bacterial communities were analyzed by gas chromatography and 454 FLX titanium pyrosequencing systems, respectively. Levels of phenols, indoles, short chain fatty acid and branched chain fatty acid were lowest $(\mathrm{p}<0.05)$ in CP $15 \%$ group among three CP levels. Relative abundance of Bacteroidetes phylum and bacterial genera including Leuconostoc, Bacillus, Atopostipes, Peptonphilus, Ruminococcaceae_uc, Bacteroides, and Pseudomonas was lower (p<0.05) in CP 15\% than in CP 20\% group. There was a positive correlation ( $\mathrm{p}<0.05)$ between odorous compounds and bacterial genera: phenol, indole, iso-butyric acid, and iso-valeric acid with Atopostipes, p-cresol and skatole with Bacteroides, acetic acid and butyric acid with AM982595_g of Porphyromonadaceae family, and propionic acid with Tissierella. Taken together, administration of $15 \%$ CP showed less production of odorous compounds than $20 \% \mathrm{CP}$ group and this result might be associated with the changes in bacterial communities especially whose roles in protein metabolism. (Key Words: Dietary Crude Protein, Pig Slurry, Phenols, Indoles, Volatile Fatty Acids, Bacterial Community)
\end{abstract}

\section{INTRODUCTION}

Intensive livestock systems have proven economically effective but many adverse effects have become evident, particularly of odor production and handling of livestock waste. From 2009 to 2013, the number of pigs has increased from 9,585 thousand to 10,097 thousand. As a consequence, animal manure also increased from 4,370 million tons in 2009 to 4,724 million tons in 2013 (MAFRA, 2013). Swine farms accounted for more than $54 \%$ among the civil complains appeal for livestock odor (MAFRA, 2010). Odor production can be affected by the type of pig house and manure treatment system. Most pig houses have been built with an opened ventilation system $(76 \%$ of the total pig houses) and slatted floor system (52\% of the total manure

\footnotetext{
* Corresponding Author: Sungkwon Park. Tel: +82-2-3408-2906, Fax: +82-2-3408-4319, E-mail: sungkwonpark@ hotmail.com ${ }^{1}$ Department of Food Science and Technology, Sejong University, Seoul 143-747, Korea.

Submitted Jan. 29, 2015; Revised Mar. 23, 2015; Accepted Apr. 3, 2015
}

treatment systems) in Korea. The odoriferous gas is continuously released from the surface of the slurry and fouled floor surfaces (MAFRA, 2010). To control livestock odor production, governments enacted strict regulations such as the livestock raising restricted zone (MEV, 2011) and the offensive odor control law (MEV, 2012).

Odor is mainly produced by anaerobic bacterial fermentation of nutrients including feed residues, endogenous products and dead intestinal bacteria from the gastrointestinal tract (GIT) and pig manure (Le et al., 2007). Odorous compounds consist of more than 230 materials (Schiffman et al., 2001) with four main groups: i) Sulfur compounds, ii) phenolic and indolic compounds, iii) volatile fatty acid (VFA), iv) ammonia and amines (Schiffman et al., 2001). These groups are classified by odor intensity determined by the concentration of odorous compounds and the odor activity value (OAV), which represents the odor nuisance for each person (Trabue et al., 2006). Carbohydrate is catabolized to short chain fatty acid (SCFA), $\mathrm{CO}_{2}, \mathrm{H}_{2}$, and $\mathrm{CH}_{4}$ and protein is the precursor for

Copyright @ 2015 by Asian-Australasian Journal of Animal Sciences This is an open-access article distributed under the terms of the Creative Commons Attribution Non-Commercial License (http://creativecommons.org/licenses/by-nc/3.0/), which permits unrestricted non-commercial use, distribution, and reproduction in any medium, provided the original work is properly cited. 
SCFA, branched chain fatty acid (BCFA), phenols, indoles, sulfur, ammonia and amine (Jensen and Jørgensen, 1994). Odoriferous compounds are mainly produced via the process of protein degradation rather than that of carbohydrate and a large amount of dietary protein (about 12 to 18 g per day) enters the GIT (Davila et al., 2013). Endogenous protein sources including intestinal epithelial cells, enzymes and dead bacteria also contribute to production of malodorous compounds (Aarnink, 1997; Van der Meulen et al., 2008). About $70 \%$ of $\mathrm{N}$ consumed is excreted by pigs, providing a nutrient source for bacterial fermentation resulting in generation of malodorous compounds (Aarnink, 1997).

Large numbers of bacteria and their societies exist in GIT and manure of pigs which can be categorized into thousands of bacterial taxonomies (Gill et al., 2006). Among the bacterial genera, Bacteroides, Clostridium, Propionibacterium, Fusobacterium, Streptococcus, and Lactobacillus play roles in regulating the protein metabolism (Riepe et al., 1980; Gaskins, 2001). Although many efforts have been made to investigate the composition of the global microbial community in pig slurry, precise mechanisms of how these bacteria and their metabolites respond to the changes in dietary proteins are still unknown (Smith and Macfarlane, 1998; Edwards et al., 2004; Van der Meulen et al., 2008; David et al., 2013). Recent molecular techniques, such as pyrosequencing analysis, have proven very effective for characterizing the microbial communities in pig manure. Therefore, by using these techniques, this study was performed to investigate the effect of different levels of dietary $\mathrm{CP}$ on the concentration of odorous compounds and the interrelationship between odorous compounds and bacterial communities in pig slurry.

\section{MATERIALS AND METHODS}

\section{Experimental design, animals and diets}

The experimental protocols describing the management and care of animals were reviewed and approved by the Animal Care and Use of National Institute of Animal Science. The composition of odorous compounds and bacterial communities in slurry of growing pigs fed different levels of CP $(20 \%, 17.5 \%$, and $15 \%)$ was analyzed. A total of 48 male pigs ([LandracexYorkshire] $\times$ Duroc) were randomly allocated into 3 levels of $\mathrm{CP}$ groups with 4 litters and 4 pigs per each treatment. The average initial body weight (BW) was $45 \mathrm{~kg}$. Slurry pit under the slatted floor of pig house was separated for each litter. The wall ventilation rate of pig house was adjusted by automatic controller based on the inside room temperature and the humidity. The average temperature and relative humidity of pig house were maintained at $20^{\circ} \mathrm{C}$ to $25^{\circ} \mathrm{C}$ and $60 \%$, respectively.

Diets were formulated according to the Korean Feeding
Standard, Swine (NIAS, 2012). Ingredient and nutrient composition for diets are shown in Table 1. The amount of feed offered was $5 \%$ of BW, and feeding was divided into two equivalent meals per day. After a 10-d adaptation

Table 1. Ingredient composition of experimental diets (as-fed basis)

\begin{tabular}{|c|c|c|c|}
\hline \multirow{2}{*}{ Ingredient } & \multicolumn{3}{|c|}{ Dietary CP levels (\%) } \\
\hline & 20 & 17.5 & 15 \\
\hline \multicolumn{4}{|l|}{ Composition calculated (\%) } \\
\hline Corn, yellow & 56.65 & 57.59 & 58.59 \\
\hline Soybean meal & 33.04 & 26.09 & 17.09 \\
\hline Corn gluten feed & 0.00 & 5.33 & 12.32 \\
\hline Molasses & 5.00 & 5.00 & 5.00 \\
\hline Sugar & 3.00 & 3.00 & 3.00 \\
\hline Limestone & 0.79 & 0.76 & 0.71 \\
\hline Dicalcium phosphase & 0.54 & 0.72 & 0.97 \\
\hline Soybean oil & 0.29 & 0.86 & 1.66 \\
\hline Salt & 0.25 & 0.25 & 0.25 \\
\hline Vitamin $^{1}$ and mineral mixture ${ }^{2}$ & 0.35 & 0.35 & 0.35 \\
\hline L-lysine $\cdot \mathrm{HCl}$ & 0.09 & 0.05 & 0.06 \\
\hline \multicolumn{4}{|l|}{ Composition analyzed (\%) } \\
\hline Crude protein & 18.75 & 15.92 & 13.80 \\
\hline $\mathrm{DE}(\mathrm{kcal} / \mathrm{kg})$ & 3,983 & 3,977 & 3,788 \\
\hline Crude fiber & 2.35 & 2.92 & 2.84 \\
\hline $\mathrm{Ca}$ & 1.02 & 0.75 & 1.02 \\
\hline $\mathrm{P}$ & 0.49 & 0.51 & 0.59 \\
\hline \multicolumn{4}{|l|}{ Indispensable amino acids } \\
\hline Arginine & 1.13 & 0.99 & 0.80 \\
\hline Histidine & 0.49 & 0.43 & 0.36 \\
\hline Isoleucine & 0.72 & 0.60 & 0.49 \\
\hline Leucine & 1.64 & 1.45 & 1.25 \\
\hline Lysine & 1.08 & 0.84 & 0.65 \\
\hline Methionine & 0.22 & 0.18 & 0.17 \\
\hline Phenylalanine & 0.90 & 0.76 & 0.61 \\
\hline Threonine & 0.72 & 0.63 & 0.51 \\
\hline Valine & 0.77 & 0.67 & 0.58 \\
\hline \multicolumn{4}{|l|}{ Dispensable amino acids } \\
\hline Alanine & 0.93 & 0.84 & 0.75 \\
\hline Aspartate & 1.92 & 1.62 & 1.25 \\
\hline Cysteine & 0.26 & 0.23 & 0.23 \\
\hline Glutamate & 3.47 & 3.17 & 2.53 \\
\hline Glycine & 0.77 & 0.67 & 0.55 \\
\hline Proline & 1.02 & 0.95 & 0.84 \\
\hline Serine & 0.92 & 0.80 & 0.63 \\
\hline Tyrosine & 0.58 & 0.50 & 0.44 \\
\hline
\end{tabular}

$\mathrm{CP}$, crude protein; $\mathrm{DE}$, digestible energy.

${ }^{1}$ Provided the following amounts per kilogram of diet: vitamin A 5,500 IU; vitamin $\mathrm{D}_{3} 550 \mathrm{IU}$; vitamin E $27 \mathrm{IU}$; menadione sodium bisulfate 2.5 $\mathrm{mg}$; pantothenic acid $27 \mathrm{mg}$; niacin $33 \mathrm{mg}$; riboflavin $5.5 \mathrm{mg}$; vitamin $\mathrm{B}_{12} 0.04 \mathrm{mg}$; thiamin $5 \mathrm{mg}$; pyridoxine $3 \mathrm{mg}$; biotin $0.24 \mathrm{mg}$; folic acid $1.5 \mathrm{mg}$; choline chloride $700 \mathrm{mg}$.

${ }^{2}$ Provided the following per kilogram of diet: choline chloride $700 \mathrm{mg}$; selenium $0.15 \mathrm{mg}$; manganese $0.03 \mathrm{~g}$; zinc $0.1 \mathrm{~g}$; iron $0.1 \mathrm{~g}$; iodine 0.5 $\mathrm{mg}$; magnesium $0.1 \mathrm{~g}$. 
period which allows pigs to acclimatize to the experimental diets, the slurry pits were cleaned before collection started.

\section{Slurry collection and odorous compounds analysis}

Slurry collection: Sample collection was performed under the same condition across all treatments in this study. Slurry was collected from the pit of each litter per every week during 1 month of the experimental period. Slurry sample was stored in a freezer $\left(-20^{\circ} \mathrm{C}\right)$ until analysis. Odorous compounds including VFA, phenols and indoles were measured by gas chromatography (GC).

Volatile fatty acid: Five milliliters of slurry sample was mixed with $1 \mathrm{~mL}$ of $25 \%$ meta-phosphoric acid (Sigmaaldrich, St. Louis, MO, USA) solution and $0.05 \mathrm{~mL}$ of saturated mercury (II) chloride (Sigma-aldrich, USA) solution in a $15 \mathrm{~mL}$ plastic tube. The mixed solution was then centrifuged at $4,000 \mathrm{rpm}$ for $20 \mathrm{~min}$ at $20^{\circ} \mathrm{C}$, and $1 \mathrm{~mL}$ of supernatant was transferred to $1.5 \mathrm{~mL}$ tube. The supernatant was subsequently centrifuged for $10 \mathrm{~min}$ at $12,000 \mathrm{rpm}$ and filtered through a $0.2 \mu \mathrm{m}$ filter (Whatman, Uppsala, Sweden). Filtrates were transferred to $2.0 \mathrm{~mL} \mathrm{GC}$ vial (Agilent, Santa Clara, CA, USA). Concentration of VFA was analyzed using a GC (6890N, Agilent, USA) equipped with HP-INNOWax column ( $30 \mathrm{~m} \times 0.25 \mathrm{~mm} \times 0.25$ $\mu \mathrm{m}$, Agilent, USA) and flame ionization detector (FID). The oven temperature was programmed to initial temperature of $80^{\circ} \mathrm{C}$ for $2 \mathrm{~min}$, increasing to $120^{\circ} \mathrm{C}$ at a rate of $20^{\circ} \mathrm{C} / \mathrm{min}$, increasing to $205^{\circ} \mathrm{C}$ at a rate of $10^{\circ} \mathrm{C} / \mathrm{min}$, and holding at $205^{\circ} \mathrm{C}$ for $2 \mathrm{~min}$. The injection and detection ports were maintained at $250^{\circ} \mathrm{C}$. The sample injection volume was 0.2 $\mu \mathrm{L}$ with a 10:1 split ratio.

Phenols and indoles: Slurry samples were centrifuged at $4,000 \mathrm{rpm}$ for $20 \mathrm{~min}$ at $20^{\circ} \mathrm{C}$. The $4 \mathrm{~mL}$ of supernatant was mixed with $4 \mathrm{~mL}$ of chloroform (Merck, Darmstadt, Germany) and $60 \mu \mathrm{L}$ of $4 \mathrm{M}$ sodium hydroxide (Sigmaaldrich, USA) solution in $20 \mathrm{~mL}$ glass vial. The mixed solution was centrifuged at $4,000 \mathrm{rpm}$ for $20 \mathrm{~min}$ at $20^{\circ} \mathrm{C}$, and chloroform layer was transferred to $2.0 \mathrm{~mL} \mathrm{GC}$ vial (Agilent, USA). Phenols and indoles were analyzed using a GC (6890N, Agilent, USA) equipped with DB-1 column (30 $\mathrm{m} \times 0.25 \mathrm{~mm} \times 0.25 \mu \mathrm{m}$, Agilent, USA) and FID. The oven temperature was programmed to initial temperature of $40^{\circ} \mathrm{C}$ for $5 \mathrm{~min}$, increasing to $230^{\circ} \mathrm{C}$ at a rate of $10^{\circ} \mathrm{C} / \mathrm{min}$, and holding at $230^{\circ} \mathrm{C}$ for $2 \mathrm{~min}$. The injection and detection ports were maintained at $250^{\circ} \mathrm{C}$. The sample injection volume was $2.0 \mu \mathrm{L}$ with a 5:1 split ratio.

\section{Bacterial community analysis}

Polymerase chain reaction amplification for bar-coded pyrosequencing: Total genomic DNA from slurry samples was extracted using a Fast-DNA spin kit (MP bio, Santa Ana, CA, USA) according to the manufacturer's instructions. Also, PCR interfering substances such as humic acid were removed using a Power-Clean DNA Clean-Up kit (MP bio, USA). Bacterial 16S ribosomal RNA (16S rRNA) genes around 500 to $700 \mathrm{bp}$ containing V1 to $\mathrm{V} 3$ of the variable region were amplified using primer set (forward 27F 5'-adaptor 2-AC-GAG TTT GAT CMT GGC TCA G-3', reverse 518R 5'-adaptor 1-AC-X-WTT ACC GCG GCT GCT GG-3") where "X" denotes unique 7 to 11 bar-code sequences inserted between the 454 Life Sciences adaptor A sequence and the common linkers, AC (Chun et al., 2010). Polymerase chain reaction (PCR) amplification conditions were initially 1 cycle of $95^{\circ} \mathrm{C}$ for $5 \mathrm{~min}$, followed by 30 cycles of $95^{\circ} \mathrm{C}$ for $30 \mathrm{~s}, 55^{\circ} \mathrm{C}$ for $30 \mathrm{~s}$ and $72^{\circ} \mathrm{C}$ for $30 \mathrm{~s}$, and finally 1 cycle of $72^{\circ} \mathrm{C}$ for $7 \mathrm{~min}$.

Pyrosequencing and data analysis: Pyrosequencing was performed by ChunLab (Seoul, Korea) using a 454 FLX titanium system (Roche, Pleasanton, CA, USA). Sequencing reads were assigned to specific samples based on their unique barcodes. Then barcode, linker and PCR primer sequences at both sides were removed from the original sequencing reads. The final pyrosequencing reads for subsequent analysis were selected by a filtering process where reads containing more than 300 base pairs and more than average quality score (value of 25). Taxonomic assignment of the bacterial high quality reads were performed using the EzTaxon-e database (Kim et al., 2012) and a robust global pairwise sequencing alignment, coupled with the BLASTN search tool (http://www.ncbi. nlm.nih.gov/BLASTN). Sequences that could not be matched to the EzTaxon-e database at the species level (>97\%) were subjected to a secondary process that checked for chimeric sequences using the UCHIME program (Edgar et al., 2011). Operational taxonomic unit (OTU) was generated using CD-HIT program at a 97\% similarity level. The Shannon-Weaver diversity index, Chao1 richness index and Goods library coverage were calculated by the Mothur package (Schloss et al., 2009).

\section{Statistical analysis}

Odorous compounds data was subjected to analysis of variance for a completely randomized design using general linear model procedures of SAS (SAS, 2002). The concentration of odorous compounds was compared by significantly difference among means of treatment and control using Duncan's multiple range tests (Duncan, 1955). Pearson's correlation coefficient analysis using SAS (SAS, 2002) was used to link the relative abundance of bacterial species to the concentration of odorous compounds. The threshold for significance was $\mathrm{p}<0.05$ for all measured variables.

\section{RESULTS}

Effects of dietary crude protein levels on concentration 


\section{of odorous compounds in slurry}

The effects of dietary treatments on phenols, indoles and VFA concentration are shown in Table 2. In CP 20\%, $17.5 \%$, and $15 \%$ treatments, levels of phenols were 24.03 , 28.84 , and $15.58 \mathrm{mg} / \mathrm{L}(\mathrm{p}<0.05)$, and indoles 3.67, 3.04, and $2.12 \mathrm{mg} / \mathrm{L}(\mathrm{p}<0.05)$, respectively. The $15 \% \mathrm{CP}$ treatment had lowest concentration of phenols and indoles, showing a decrease in phenols by $35 \%$ and indoles by $42 \%$ compared to $\mathrm{CP} 20 \%$ treatment, respectively. However, p-cresol concentration was greatest $(\mathrm{p}<0.05)$ in $17.5 \% \mathrm{CP}$ group among other treatment groups. Concentration of VFAs including acetic acid, propionic acid, butyric acid, isobutyric acid and iso-valeric acid was increased as a greater amount of dietary CP was added to the experimental diets. Levels of SCFA and BCFA were lowest $(\mathrm{p}<0.05)$ in CP $15 \%$ compared to other groups.

Effects of dietary crude protein levels on change of bacterial community composition in slurry

Pyrosequencing data: To characterize patterns of bacterial community structure according to dietary $\mathrm{CP}$ levels of $20 \%$ and $15 \%$, we performed a multiplex barcoded pyrosequencing technique based on 16s rRNA gene sequence on samples collected from slurry pit (Table 3). Sequencing total reads classified into 9,858 and 13,167 sequences of $\mathrm{CP} 20 \%$ and $\mathrm{CP} 15 \%$ group, respectively. After the removal of low quality reads, 7,824 (CP 20\% group) and 11,156 (CP 15\% group) bacterial reads were used for further analyses (Table 3). After trimming the PCR primers, the average read lengths were between 505 and 500 bases for CP $20 \%$ and CP 15\% group, respectively.

Table 2. Concentration of odorous compounds from pig slurry

\begin{tabular}{|c|c|c|c|c|c|}
\hline \multirow{2}{*}{ Items (mg/L) } & \multicolumn{3}{|c|}{ Dietary CP levels (\%) } & \multirow{2}{*}{ SEM } & \multirow{2}{*}{ SD } \\
\hline & 20 & 17.5 & 15 & & \\
\hline Phenol & $11.28^{\mathrm{a}}$ & $10.94^{\mathrm{a}}$ & $5.55^{\mathrm{b}}$ & 0.97 & 10.05 \\
\hline p-Cresol & $12.75^{\mathrm{b}}$ & $17.89^{\mathrm{a}}$ & $10.03^{\mathrm{b}}$ & 0.75 & 7.75 \\
\hline Indole & $2.53^{\mathrm{a}}$ & $1.76^{\mathrm{b}}$ & $1.41^{\mathrm{b}}$ & 0.13 & 1.37 \\
\hline Skatole & $1.14^{\mathrm{a}}$ & $1.29^{\mathrm{a}}$ & $0.71^{\mathrm{b}}$ & 0.05 & 0.49 \\
\hline Phenols+p-cresol & $24.03^{\mathrm{a}}$ & $28.84^{\mathrm{a}}$ & $15.58^{\mathrm{b}}$ & 1.54 & 16.04 \\
\hline Indoles+skatole & $3.67^{\mathrm{a}}$ & $3.04^{\mathrm{a}}$ & $2.12^{\mathrm{b}}$ & 0.16 & 1.69 \\
\hline Acetic acid & $1,602^{\mathrm{a}}$ & $1,615^{\mathrm{a}}$ & $868^{\mathrm{b}}$ & 99.83 & $1,037.48$ \\
\hline Propionic acid & $327^{\mathrm{a}}$ & $296^{\mathrm{ab}}$ & $246^{\mathrm{b}}$ & 15.54 & 161.50 \\
\hline Butyric acid & $289^{\mathrm{a}}$ & $222^{\mathrm{ab}}$ & $185^{\mathrm{b}}$ & 14.39 & 149.50 \\
\hline Iso-butyric acid & $76^{\mathrm{a}}$ & $59^{\mathrm{a}}$ & $37^{\mathrm{b}}$ & 4.37 & 45.38 \\
\hline Iso-valeric acid & $146^{\mathrm{a}}$ & $116^{\mathrm{a}}$ & $69^{\mathrm{b}}$ & 7.86 & 81.72 \\
\hline $\mathrm{SCFA}^{1}$ & $2,219^{\mathrm{a}}$ & $2,133^{\mathrm{a}}$ & $1,298^{\mathrm{b}}$ & 124.20 & $1,290.70$ \\
\hline $\mathrm{BCFA}^{2}$ & $222^{\mathrm{a}}$ & $175^{\mathrm{a}}$ & $106^{\mathrm{b}}$ & 12.21 & 126.90 \\
\hline
\end{tabular}

CP, crude protein; SEM, standard errors of the means; SD, standard deviation; SCFA, short chain fatty acid; BCFA, branched chain fatty acid.

${ }^{1}$ SCFA $=$ acetic acid+propionic acid+butyric acid.

${ }^{2}$ BCFA = iso-butyric acid+iso-valeric acid.

a,b,c,d Figures with different superscripts within the same row are significantly different $(\mathrm{p}<0.05)$.
Table 3. The pyrosequencing data of bacterial communities in pig slurry

\begin{tabular}{lcc}
\hline & \multicolumn{2}{c}{ Dietary CP levels (\%) } \\
\cline { 2 - 3 } & 20 & 15 \\
\hline No. of total reads & 9,858 & 13,167 \\
No. of high-quality reads & 7,824 & 11,156 \\
Aver. read length & 505 & 500 \\
OTU $^{1}$ & 1,173 & 955 \\
${\text { Shannon-Weaver index }\left(\mathrm{H}^{\prime}\right)^{1}}_{\text {Chao1 }^{1}}$ & 5.21 & 4.83 \\
Goods library coverage $^{1}$ & 2,167 & 1,562 \\
\hline
\end{tabular}

CP, crude protein; OUT, operational taxonomic units.

${ }^{1}$ Shannon-Weaver (diversity index), Chao1 (richness index) and Goods library coverage were calculated using the Mothur package.

Although the number of bacterial reads was higher in CP $15 \%$ group than CP 20\%, the number of OTUs, diversity (Shannon-Weaver index) and richness (Chao1) of bacterial communities were lower in CP $15 \%$ than CP $20 \%$ group. This result indicates the bacterial community of $\mathrm{CP} 15 \%$ group is simpler than that of CP $20 \%$ group.

Bacterial taxonomic composition: Taxonomic pyrosequencing profiles for bacterial communities from treatment groups are shown in Figure 1 and 2. At the phylum level (Figure 1), the predominant phylum was Firmicutes with relative abundance proportion of more than $70 \%$, followed by Bacteroidetes and Proteobacteria. The relative abundance of Firmicutes was not affected by dietary treatment. The relative abundance of Bacteroidetes was lower $(\mathrm{p}<0.05)$ in CP $15 \%$ group $(3.3 \%)$ compared to CP $20 \%$ group $(12.1 \%)$, whereas Proteobacteria was lower $(\mathrm{p}<0.05)$ in CP $20 \%(6.8 \%)$ than CP $15 \%$ group $(12.1 \%)$. More detailed differences are identified at the bacterial genus level (Figure 2). Among the dominant genera, Leuconostoc, Bacillus and Atopostipes of Bacilli class (Firmicutes), Peptoniphilus and Ruminococcaceae_uc of Clostridia class (Firmicutes), Bacteroides of Bacteroidia class (Bacteroidetes), and Pseudomonas of Proteobacteria class (Proteobacteria) were lower $(\mathrm{p}<0.05)$ in $\mathrm{CP} 15 \%$ than CP 20\% group. Enterococcus of Bacilli class (Firmicutes), Clostridium of Clostridia class (Firmicutes), and Comamonas of Proteobacteria class (Proteobacteria) were higher $(\mathrm{p}<0.05)$ in CP $15 \%$ than CP $20 \%$ group.

\section{Correlation of relative abundance of bacterial genus with odorous compounds from slurry}

Results of correlation analysis between bacteria genus and generation of odorous compounds in the pig slurry are shown in Table 4. Significant values of correlation coefficient were found between phenol, indole, iso-butyric acid and iso-valeric acid with Atopostipes, p-cresol and skatole with Bacteroides, acetic acid and butyric acid with AM982595_g of Porphyromonadaceae family, and 


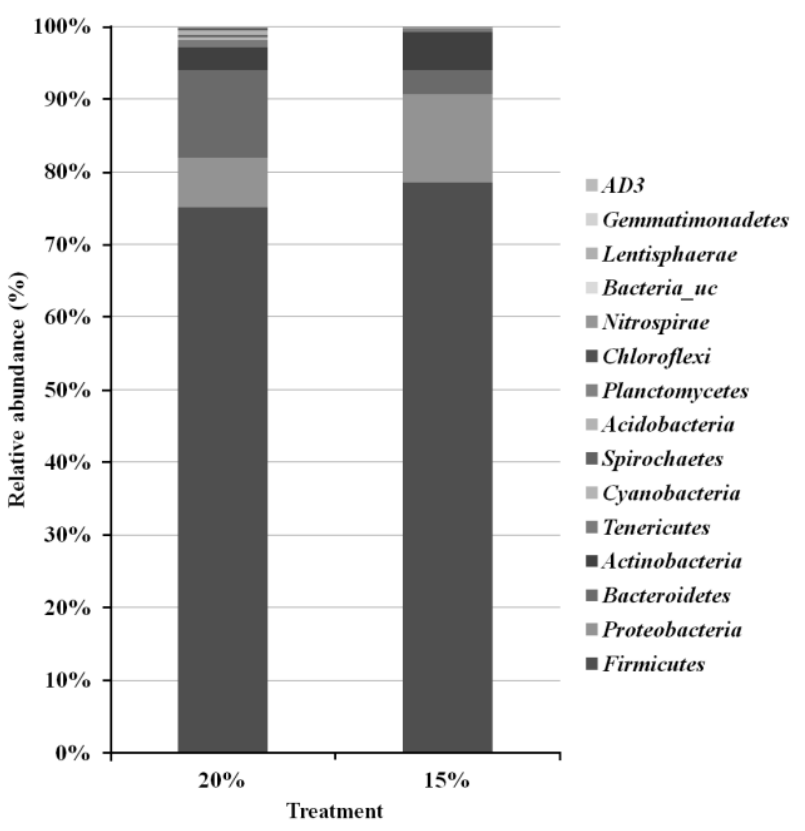

Figure 1. Bacterial taxonomic compositions of phylum level. Sequences were classified using the EzTaxon-e database.

propionic acid with Tissierella.

\section{DISCUSSION}

Attempts have been made to understand the process of odorous compound production and to control the bacterial composition both in pig GIT and manure. Since malodorous compounds are produced from anaerobic nutrient degradation by microbes, decreasing nutrient excretion is crucial for reducing odor (Sutton et al., 1999). Especially, N excretion is the major factor for production of malodorous compounds since $\mathrm{N}$ excreta causes incomplete microbial degradation (Aarnink, 1997). Therefore, this study was performed to identify the mechanisms by which microbes metabolize nutrients and to decrease the generation of odor by administration reduced CP level.

Reduced dietary CP level from $18 \%$ to $12 \%$ in pig feed decreased production of malodorous compounds including phenols, indoles, SCFA and BCFA by $40 \%$ in manure from growing pigs (Le et al., 2007) and finishing pigs (Hobbs et al., 1996), Ziemer et al. (2009). Concomitant to these data, levels of phenols, indoles, SCFA and BCFA were decreased by $35 \%$ to $40 \%$ in CP $15 \%$ group when compared with CP $20 \%$ group in our current study (Table 2). Phenols, indoles and BCFA have greater odor intensity and nuisance with a lower odor detection threshold than other compounds (Jensen and Jørgensen, 1994; Le et al., 2005). Indole, pcresol and skatole account for over $90 \%$ of the OAV among all volatile organic compounds (VOCs), which are emitted from pig buildings, manure storage sites and land application of manure. In particular, p-cresol is most responsible for the overall odor impact from the VOC emission (Trabue et al., 2008a,b; Parker et al., 2013).

Undigested dietary protein and proteins of endogenous origin pass into the GIT, which accelerates the growth of $\mathrm{N}$ utilizing bacteria that ferment protein to produce potentially malodorous compounds such as phenols, indoles and BCFA. Phenols and indoles absorbed in the large intestine are then detoxified by conjugation with glucuronic acid in liver and excreted via urine as glucuronides. In manure, urinary

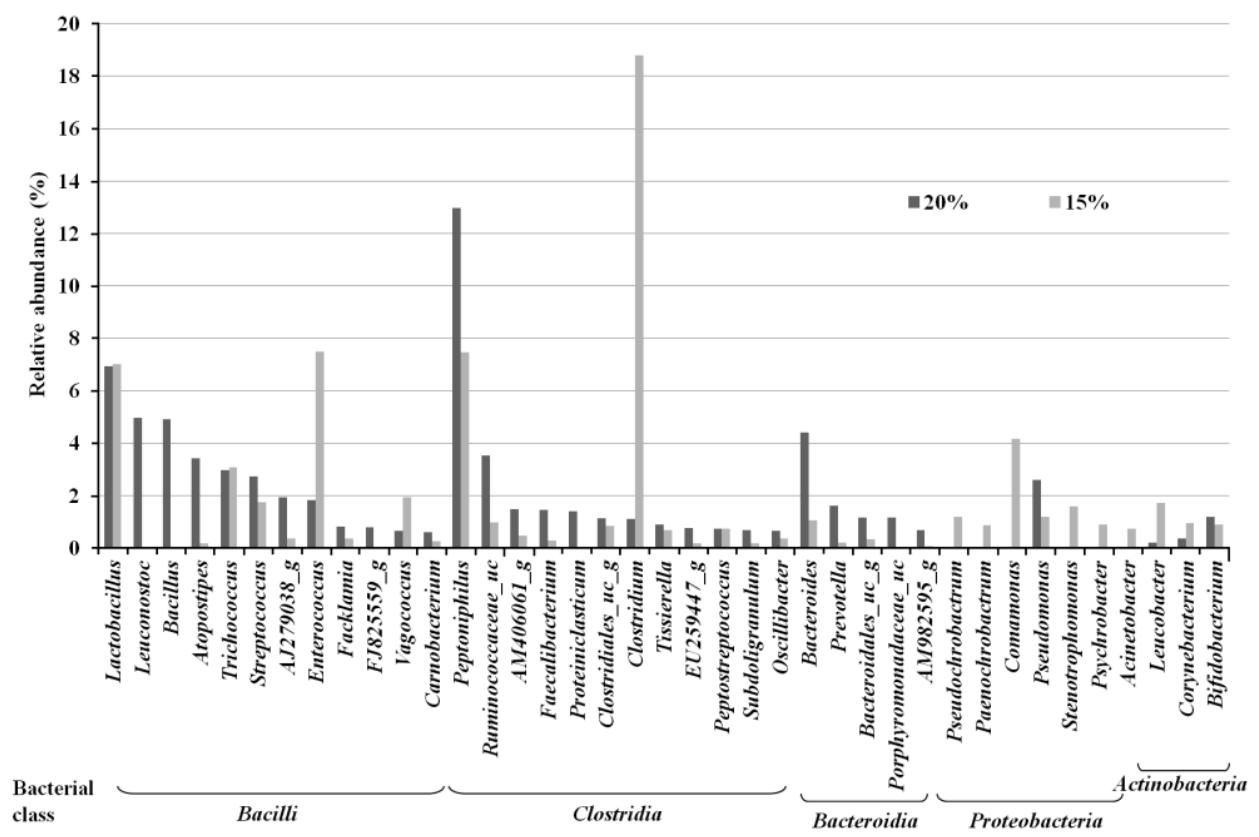

Figure 2. Bacterial taxonomic compositions of genus level. Bacterial genus were classified at a cut off level of $>0.5 \%$ relative abundance. 
Table 4. Correlation coefficient $(\mathrm{R})$ values for the relative abundance of bacterial genus with the odorous compounds in swine slurry ${ }^{1}$

\begin{tabular}{|c|c|c|c|c|c|c|c|c|c|}
\hline \multirow[b]{2}{*}{ Bacterial genus } & \multicolumn{9}{|c|}{ Odorous compounds } \\
\hline & Phenol & p-Cresol & Indole & Skatole & $\begin{array}{c}\text { Acetic } \\
\text { acid }\end{array}$ & $\begin{array}{l}\text { Propionic } \\
\text { acid }\end{array}$ & $\begin{array}{c}\text { Butyric } \\
\text { acid }\end{array}$ & $\begin{array}{l}\text { I-Butyric } \\
\text { acid }\end{array}$ & $\begin{array}{l}\text { I-Valeric } \\
\text { acid }\end{array}$ \\
\hline B-Atopostipes & 0.96 & 0.87 & 0.98 & 0.93 & 0.96 & 0.87 & 0.94 & 0.99 & 0.99 \\
\hline $\begin{array}{l}\text { B- FJ825559_g } \\
\text { (Alloiococcus_f) }\end{array}$ & 0.86 & 0.74 & 0.90 & 0.88 & 0.90 & 0.80 & 0.88 & 0.91 & 0.92 \\
\hline C-Ruminococcaceae_uc & 0.93 & 0.91 & 0.95 & 0.94 & 0.90 & 0.80 & 0.91 & 0.96 & 0.96 \\
\hline $\begin{array}{l}\text { C- AM406061_g } \\
\text { (Ruminococcaceae_f) }\end{array}$ & 0.90 & 0.91 & 0.92 & 0.95 & 0.88 & 0.77 & 0.89 & 0.93 & 0.93 \\
\hline C-Faecalibacterium & 0.92 & 0.87 & 0.94 & 0.94 & 0.88 & 0.76 & 0.88 & 0.95 & 0.95 \\
\hline C-Clostridiales_uc_g & 0.82 & 0.88 & 0.84 & 0.87 & 0.79 & 0.70 & 0.82 & 0.85 & 0.85 \\
\hline C-Tissierella & 0.83 & 0.89 & 0.84 & 0.76 & 0.90 & 0.96 & 0.93 & 0.82 & 0.82 \\
\hline $\begin{array}{l}\text { C- EU259447_g } \\
\text { (Ruminococcaceae_f) }\end{array}$ & 0.90 & 0.87 & 0.92 & 0.95 & 0.86 & 0.74 & 0.86 & 0.94 & 0.94 \\
\hline C-Subdoligranulum & 0.85 & 0.80 & 0.87 & 0.93 & 0.84 & 0.71 & 0.85 & 0.91 & 0.92 \\
\hline C-Oscillibacter & 0.85 & 0.90 & 0.87 & 0.93 & 0.82 & 0.72 & 0.85 & 0.89 & 0.88 \\
\hline Bt-Bacteroides & 0.93 & 0.93 & 0.95 & 0.97 & 0.92 & 0.83 & 0.94 & 0.96 & 0.96 \\
\hline Bt-Prevotella & 0.92 & 0.85 & 0.94 & 0.93 & 0.89 & 0.76 & 0.87 & 0.96 & 0.96 \\
\hline Bt-Porphyromonadaceae_uc & 0.95 & 0.88 & 0.96 & 0.93 & 0.90 & 0.79 & 0.89 & 0.97 & 0.97 \\
\hline $\begin{array}{l}\text { Bt- AM982595_g } \\
\text { (Porphyromonadaceae_f) }\end{array}$ & 0.91 & 0.81 & 0.95 & 0.88 & 0.96 & 0.90 & 0.95 & 0.95 & 0.96 \\
\hline
\end{tabular}

B, Bacilli class; C, Clostridia class; Bt, Bacteroidia class.

${ }^{1}$ Correlation among parameters analyzed using Pearson correlation and stepwise multiple linear regression models $(\mathrm{p}<0.05, \mathrm{R}>0.9)$.

glucuronides are hydrolysed by fecal $\beta$-glucuronidase to release phenols and indoles (Le et al., 2005). A positive correlation between dietary protein intake and urinary phenol excretion has been reported in pigs (Otto et al., 2003a). The reduction in $\mathrm{N}$ excretion in response to reduced dietary $\mathrm{CP}$ levels also results in modulating bacterial fermentation in pig manure. (Sørensen and Fernández, 2003). Therefore, a decrease in dietary CP concentration from $20 \%$ to $15 \%$ could be responsible for the reduction of phenols, indoles and BCFA that are metabolized during protein fermentation (Hernández et al., 2011). Further studies are necessary to reduce the odor production using feeding strategies for optimal rather than maximum performance with optimal nutrient requirements according to growing stage or physiological state (Dourmad and Jondreville, 2007).

Relationship between composition of odorous compounds and bacterial community was analyzed by a multiplex bar-coded pyrosequencing technique. Contrary to previous studies using the culture-based bacterial count techniques, pyrosequencing technique is cultureindependent and provides more precise information about the bacterial community dwelling in natural habitats. In particular, a multiplex bar-coded pyrosequencing technique based on 16s rRNA gene sequences can identify the bacterial community comprising as little as $1 \%$ of the total population (Hamady et al., 2008). Therefore, this technique has been used to analyze the multiple bacteria in the large intestine and the manure, and to explore new bacterial communities related to the production of odorous compounds.

Nitrogen and amino acid from protein provides energy sources for the growth of saccharolytic and asaccharolytic bacteria (Scott et al., 2013). Excessive supply of dietary CP to pigs can lead a vigorous growth of various intestinal bacteria since excessive or indigestible protein serves as a fermentation substrate for bacteria (Rist et al., 2013). We found that diversity of the communities was lower in $\mathrm{CP}$ $15 \%$ group than CP $20 \%$ group (Table 3 ) suggesting that these communities are very sensitive to subtle changes in dietary CP levels fed to pigs.

Similar to previous reports (Lamendella et al., 2011; Ziemer, 2013), bacterial taxonomic profiles identified in the current study showed that Firmicutes, Bacteroidetes, and Proteobacteria were the predominant species (Figure 1). Firmicutes and Bacteroidetes, which constitute the majority of the gut bacteria, are associated with carbohydrate and protein metabolism. Bacteria in these two phyla are used as a phylogenetic marker since their abundance is easily influenced according to the fermentation condition in GIT (Ramakrishna, 2013). In our study, the relative abundance of Bacteroidetes was higher but Proteobacteria was lower in CP $20 \%$ group compared to CP $15 \%$ group.

Changes in bacterial abundance are correlated with the composition of malodorous compounds produced in pig manure. Skatole, one of the most malodorous compounds, can be produced during the process of deamination and decarboylation of tryptophan by bacterial strains of 
Bacteroidetes (Chung et al., 1975). Conversely, Proteobacteria, which are intolerance to skatole, showed a relatively low abundance in samples with high levels (Attwood et al., 2006; Cook et al., 2007). Most of bacterial genus produces VFA, phenols and indoles while they metabolize the amino acids. Bacteroides, Propionibacterium, Clostridium, Eubacterium, and Streptococcus metabolize glycine, alanine, threonine, glutamate, lysine and aspartate to acetic acid. The microbial metabolism of amino acids also leads to formation of other VFAs; butyric acid from glutamate and lysine, propionic acid from alanine and threonine, iso-butyric acid from valine, and iso-valeric acid from leucine and isoleucine. In addition, Bacteroides, Lactobacillus, Bifidobacterium, Clostridium, and Peptostreptococcus generate phenols and indoles by metabolizing aromatic compounds such as tyrosine and tryptophan (Zhu, 2000; Le et al., 2005; Davila et al., 2013). Leuconostoc, Bacillus, Atopostipes, Bacteroides, and Pseudomonas metabolize tryptophan to indole-3-lactate, and then to indole and skatole in animal feces (Chen and Russell, 1988; Starrenburg and Hugenholtz, 1991; Van der Meulen et al., 2008; Keseler et al., 2013). Distribution of these indole- and skatole-producers was lower in CP $15 \%$ group than $20 \%$ group in our current study. Also, Bacillus, Bacteroides, and Pseudomonas produce BCFA through deamination of branched-chain amino acid such as leucine, isoleucine and valine (Macfarlane and Macfarlane, 1995; Van der Meulen et al., 2008; Keseler et al., 2013). Bacteroides species secreting various amounts of protease decompose endogenous and exogenous proteins. The bacterial protease behaves akin to elastase and destroys maltase and sucrase from brush borders (Riepe et al., 1980; Gaskins, 2001). Peptoniphilus, non-saccharolytic bacteria, can utilize protein as an energy source and produce BCFA and indole (Keseler et al., 2013). When compared to Bacteroides, Clostridium, which takes a greater proportion in the lower CP group (15\%) than in the higher CP group (20\%), produces less amounts of SCFA, BCFA, and indoles (Cook et al., 2007; Keseler et al., 2013). These results indicate that changes in dietary protein level modulate the composition of the bacterial community and the abundance of the relative microbial society. Consequently, in the 10 genera of representative genus which are different between $15 \%$ and $20 \%$ dietary CP group, the number of bacterial genera related to production of phenols, indoles and BCFA was fewer in CP 15\% (1 genus) than in CP 20\% (6 genera). Moreover, a total proportion of microbial abundance was lower in CP 15\% (28\%) than in CP 20\% (35\%).

The correlation analysis was performed to understand the association of odorous compounds with the relative abundance of bacterial genera in pig slurry (Table 4). Phenol, indole, iso-butyric acid and iso-valeric acid were displayed a strong positive correlation with Atopostipes.
Atopostipes is a bacterial genus of Lactobacilliales order under the Bacilli class which is a gram positive bacterium. As a member of lactic acid bacteria, it metabolizes valine and tryptophan to BCFA and indole (Cotta et al., 2004; Keseler et al., 2013). Atopostipes also showed a strong positive correlation with phenol in VOCs from chicken litter (Wadud, 2011). Bacteroides, which is a genus of gram-negative and an obligately anaerobic bacteria, possesses an effective barrier to hydrophobic molecules and therefore can metabolize hydrophobic amino acids including tyrosine and tryptophan as well as aromatic amino acids into phenols, indoles and their precursors (Smith and Macfarlane, 1998; Van der Meulen et al., 2008). Production of p-cresol and skatole is also positively correlated with Bacteroides. We found strong positive correlations in acetic acid and butyric acid with AM982595_g of Porphyromonadaceae family, and propionic acid with Tissierella. Members of Porphyromonadaceae family produce various VFAs. In particular, proteolytic bacteria of this family generates acetic acid, propionic acid and butyric acid from various amino acids (Sakamoto et al., 2009; Ziganshin et al., 2011). Tissierella, a genus of gram-positive bacteria, first isolated from human feces, produces acetate as intermediates of creatinine breakdown (Harms et al., 1998). These results indicate that there was a strong positive correlation between Atopostipes and Bacteroides with malodorous compounds including phenols, indoles and BCFA.

\section{CONCLUSION}

Results from the current study indicate that adjustment of dietary CP level affects the composition of odorous compounds as well as the bacterial community. Supplementation of $15 \% \mathrm{CP}$ rather than $20 \% \mathrm{CP}$ significantly reduced odorous compounds in pig slurry. Taxonomic pyrosequencing analysis revealed a strong relationship between odorous compounds and bacterial community. Altogether, it remains to be analyzed how gut bacteria and bacterial metabolites respond to dietary change, the subjects of the experiment mainly focused on feces of human and luminal content of ruminants (Smith and Macfarlane, 1998; Van der Meulen et al., 2008; Norrapoke et al., 2012). Moreover, bacterial metabolites were mostly fatty acids and sulfur compounds (Alam et al., 2012). Therefore our results provide valuable new information concerning the production of odor in the context of nutrient metabolism and bacterial ecology, and an important first step towards controlling odor production in pig manure. Further research will focus on identifying the precise mechanism of bacterial metabolism and exploiting the prediction model of odor production in pig houses. 


\section{ACKNOWLEDGMENTS}

This study was carried out with the support of "Practical use of odor reducing agent developed to synbiotic technology for pigpen (Project No. PJ01026301)" by the National Institute of Animal Science (NIAS), Suwon, Republic of Korea.

\section{REFERENCES}

Aarnink, A. J. A. 1997. Ammonia emission from houses for growing pigs as affected by pen design, indoor climate and behaviour. Droevendaalsesteeg PB Wageningen, Netherlands.

Alam, M. J., C. D. Jeong, L. L. Mamuad, H. G. Sung, D. W. Kim, S. B. Cho, K. Lee, C. O. Jeon, and S. S. Lee. 2012. Bacterial community dynamics during swine in vitro fermentation using starch as a substrate with different feed additives for odor reduction. Asian Australas. J. Anim. Sci. 25:690-700.

Chen, G. J. and J. B. Russell. 1988. Fermentation of peptides and amino acids by a monensin-sensitive ruminal Peptostreptococcus. Appl. Environ. Microbiol. 54:2742-2749.

Chun, J., K. Y. Kim, J.-H. Lee, and Y. Choi. 2010. The analysis of oral microbial communities of wild-type and toll-like receptor 2-deficient mice using a 454 GS FLX Titanium pyrosequencer. BMC Microbiol. 10:101.

Chung, K. T., G. M. Anderson, and G. E. Fulk. 1975. Formation of indoleacetic acid by intestinal anaerobes. J. Bacteriol. 124:573575.

Cook, K. L., M. J. Rothrock, J. H. Loughrin, and K. C. Doerner. 2007. Characterization of skatole-producing microbial populations in enriched swine lagoon slurry. FEMS Microbiol. Ecol. 60:329-340.

Cotta, M. A., T. R. Whitehead, M. D. Collins, and P. A. Lawson. 2004. Atopostipes suicloacale gen. nov., sp. nov., isolated from an underground swine manure storage pit. Anaerobe 10:191195.

David, L. A., C. F. Maurice, R. N. Carmody, D. B. Gootenberg, J. E. Button, B. E. Wolfe, A. V. Ling, A. S. Devlin, Y. Varma, and M. A. Fischbach et al. 2013. Diet rapidly and reproducibly alters the human gut microbiome. Nature 505(7484):559-563.

Davila, A.-M., F. Blachier, M. Gotteland, M. Andriamihaja, P.-H. Benetti, Y. Sanz, and D. Tomé. 2013. Intestinal luminal nitrogen metabolism: Role of the gut microbiota and consequences for the host. Pharmacol. Res. 68:95-107.

Dourmad, J.-Y. and C. Jondreville. 2007. Impact of nutrition on nitrogen, phosphorus, $\mathrm{Cu}$ and $\mathrm{Zn}$ in pig manure, and on emissions of ammonia and odours. Livest. Sci. 112:192-198.

Duncan, D. B. 1955. Multiple range and multiple $F$ tests. Biometrics 11:1-42.

Edgar, R. C., B. J. Haas, J. C. Clemente, C. Quince, and R. Knight. 2011. UCHIME improves sensitivity and speed of chimera detection. Bioinformatics. 27:2194-2200.

Edwards, J. E., N. R. McEwan, A. J. Travis, and R. J. Wallace. 2004. 16S rDNA library-based analysis of ruminal bacterial diversity. Antonie Van Leeuwenhoek 86:263-281.

Gaskins, H. R. 2001. Intestinal bacteria and their influence on swine growth. CRC Press, Boca Raton, FL, USA.

Gill, S. R., M. Pop, R. T. DeBoy, P. B. Eckburg, P. J. Turnbaugh, B.
S. Samuel, J. I. Gordon, D. A. Relman, C. M. Fraser-Liggett, and K. E. Nelson. 2006. Metagenomic analysis of the human distal gut microbiome. Science 312(5778):1355-1359.

Hamady, M., J. J. Walker, J. K. Harris, N. J. Gold, and R. Knight. 2008. Error-correcting barcoded primers for pyrosequencing hundreds of samples in multiplex. Nat. Methods 5:235-237.

Harms, C., A. Schleicher, M. D. Collins, and J. R. Andreesen. 1998. Tissierella creatinophila sp. nov., a Gram-positive, anaerobic, non-spore-forming, creatinine-fermenting organism. Int. J. Syst. Bacteriol. 48:983-993.

Hernández, F., S. Martínez, C. López, M. D. Megías, M. López, and J. Madrid. 2011. Effect of dietary crude protein levels in a commercial range, on the nitrogen balance, ammonia emission and pollutant characteristics of slurry in fattening pigs. Animal. 5:1290-1298.

Hobbs, P. J., B. F. Pain, R. M. Kay, and P. A. Lee. 1996. Reduction of odorous compounds in fresh pig slurry by dietary control of crude protein. J. Sci. Food Agric. 71:508-514.

Jensen, B. B. and H. Jørgensen. 1994. Effect of dietary fiber on microbial activity and microbial gas production in various regions of the gastrointestinal tract of pigs. Appl. Environ. Microbiol. 60:1897-1904.

Keseler, I. M., A. Mackie, M. Peralta-Gil, A. Santos-Zavaleta, S. Gama-Castro, C. Bonavides-Martínez, C. Fulcher, A. M. Huerta, A. Kothari, and M. Krummenacker et al. 2013. EcoCyc: Fusing model organism databases with systems biology. Nucl. Acids Res. 41(D1):D605-D612.

Kim, O.-S., Y.-J. Cho, K. Lee, S.-H. Yoon, M. Kim, H. Na, S.-C. Park, Y. S. Jeon, J.-H. Lee, H. Yi, S. Won, and J. Chun. 2012. Introducing EzTaxon-e: a prokaryotic 16S rRNA gene sequence database with phylotypes that represent uncultured species. Int. J. Syst. Evol. Microbiol. 62(Pt 3):716-721.

Lamendella, R., J. W. Santo Domingo, S. Ghosh, J. Martinson, and D. B. Oerther. 2011. Comparative fecal metagenomics unveils unique functional capacity of the swine gut. BMC Microbiol. 11:103.

Le, P. D., A. J. A. Aarnink, A. W. Jongbloed, C. M. C. PeetSchwering, N. W. M. Ogink, and M. W. A. Verstegen. 2007. Effects of dietary crude protein level on odour from pig manure. Animal 1:734-744.

Le, P. D., A. J. A. Aarnink, N. W. M. Ogink, P. M. Becker, and M. W. A. Verstegen. 2005. Odour from animal production facilities: its relationship to diet. Nutr. Res. Rev. 18:3-30.

Macfarlane, S. M. G. T. and G. T. Macfarlane. 1995. Proteolysis and amino acid fermentation. CRC Press, Boca Raton, FL, USA.

MAFRA. 2010. Ministry of agriculture, food and rural affairs annual report 2010. Ministry of Agriculture Food and Rural Affairs, Sejong, Korea.

MAFRA. 2013. Ministry of agriculture, food and rural affairs annual report 2013. Ministry of Agriculture Food and Rural Affairs, Sejong, Korea.

MEV. 2011. Law on livestock excretions management and usage. Ministry of Environment, Sejong, Korea.

MEV. 2012. Law on offensive odor control. Ministry of Environment, Sejong, Korea.

NIAS. 2012. Korean feeding standard, swine. National Institute of Animal Science, Wanju, Korea. 
Norrapoke, T., M. Wanapat, and S. Wanapat. 2012. Effects of protein level and mangosteen peel pellets (Mago-pel) in concentrate diets on rumen fermentation and milk production in lactating dairy crossbreds. Asian Australas. J. Anim. Sci. 25: 971-979.

Otto, E. R., M. Yokoyama, S. Hengemuehle, R. D. Von Bermuth, T. Van Kempen, and N. L. Trottier. 2003a. Ammonia, volatile fatty acids, phenolics, and odor offensiveness in manure from growing pigs fed diets reduced in protein concentration. J. Anim. Sci. 81:1754-1763.

Parker, D. B., J. Gilley, B. Woodbury, K.-H. Kim, G. Galvin, S. L. Bartelt-Hunt, X. Li and D. D. Snow. 2013. Odorous VOC emission following land application of swine manure slurry. Atmos. Environ. 66:91-100.

Ramakrishna, B. S. 2013. Role of the gut microbiota in human nutrition and metabolism. J. Gastroenterol. Hepatol. 28(S4):917.

Riepe, S. P., J. Goldstein, and D. H. Alpers. 1980. Effect of secreted Bacteroides proteases on human intestinal brush border hydrolases. J. Clin. Invest. 66:314-322.

Rist, V. T. S., E. Weiss, M. Eklund, and R. Mosenthin. 2013. Impact of dietary protein on microbiota composition and activity in the gastrointestinal tract of piglets in relation to gut health: A review. Animal 7:1067-1078.

Sørensen, P. and J. A. Fernández. 2003. Dietary effects on the composition of pig slurry and on the plant utilization of pig slurry nitrogen. J. Agric. Sci. 140:343-355.

Sakamoto, M., A. Takagaki, K. Matsumoto, Y. Kato, K. Goto, and Y. Benno. 2009. Butyricimonas synergistica gen. nov., sp. nov. and Butyricimonas virosa sp. nov., butyric acid-producing bacteria in the family 'Porphyromonadaceae' isolated from rat faeces. Int. J. Syst. Evol. Microbiol. 59:1748-1753.

SAS. 2002. SAS/STAT Software, Version 9.1. SAS Institute Inc., Cary, NC, USA.

Schiffman, S. S., J. L. Bennett, and J. H. Raymer. 2001. Quantification of odors and odorants from swine operations in North Carolina. Agric. Forest Meteorol. 108:213-240.

Schloss, P. D., S. L. Westcott, T. Ryabin, J. R. Hall, M. Hartmann, E. B. Hollister, R. A. Lesniewski, B. B. Oakley, D. H. Parks, and C. J. Robinson et al. 2009. Introducing mothur: Opensource, platform-independent, community-supported software for describing and comparing microbial communities. Appl. Environ. Microbiol. 75:7537-7541.
Scott, K. P., S. W. Gratz, P. O. Sheridan, H. J. Flint, and S. H. Duncan. 2013. The influence of diet on the gut microbiota. Pharmacol. Res. 69:52-60.

Smith, E. A. and G. T. Macfarlane. 1998. Enumeration of amino acid fermenting bacteria in the human large intestine: effects of $\mathrm{pH}$ and starch on peptide metabolism and dissimilation of amino acids. FEMS Microbiol. Ecol. 25:355-368.

Starrenburg, M. J. C. and J. Hugenholtz. 1991. Citrate fermentation by Lactococcus and Leuconostoc spp. Appl. Environ. Microbiol. 57:3535-3540.

Sutton, A. L., K. B. Kephart, M. W. Verstegen, T. T. Canh, and P. J. Hobbs. 1999. Potential for reduction of odorous compounds in swine manure through diet modification. J. Anim. Sci. 77:430439.

Trabue, S. L., J. C. Anhalt, and J. A. Zahn. 2006. Bias of tedlar bags in the measurement of agricultural odorants. J. Environ. Qual. 35:1668-1677.

Trabue, S. L., K. Scoggin, F. Mitloehner, H. Li, R. Burns, and H. Xin. 2008a. Field sampling method for quantifying volatile sulfur compounds from animal feeding operations. Atmos. Environ. 42:3332-3341.

Trabue, S. L., K. D. Scoggin, H. Li, R. Burns, and H. Xin. 2008 b. Field sampling method for quantifying odorants in humid environments. Environ. Sci. Technol. 42:3745-3750.

Van der Meulen, R., N. Camu, T. Van Vooren, C. Heymans, and L. De Vuyst. 2008. In vitro kinetic analysis of carbohydrate and aromatic amino acid metabolism of different members of the human colon. Int. J. Food Microbiol. 124:27-33.

Wadud, S. J. 2011. Understanding the microbial ecology of chicken litter in the context of odour production. Ph.D. Thesis. The university of new south wales, Sydney, Australia.

Zhu, J. 2000. A review of microbiology in swine manure odor control. Agric. Ecosyst. Environ. 78:93-106.

Ziemer, C. J. 2013. Broad diversity and newly cultured bacterial isolates from enrichment of pig feces on complex polysaccharides. Microb. Ecol. 66:448-461.

Ziemer, C. J., B. J. Kerr, S. L. Trabue, H. Stein, D. A. Stahl, and S. K. Davidson. 2009. Dietary protein and cellulose effects on chemical and microbial characteristics of swine feces and stored manure. J. Environ. Qual. 38:2138-2146.

Ziganshin, A. M., T. Schmidt, F. Scholwin, O. N. Il'inskaya, H. Harms, and S. Kleinsteuber. 2011. Bacteria and archaea involved in anaerobic digestion of distillers grains with solubles. Appl. Microbiol. Biotechnol. 89:2039-2052. 